\title{
Reflection on Multicultural Education under the Background of Globalization
}

\author{
Lihua Geng ${ }^{1}$ \\ ${ }^{1}$ Changchun University of Science and Technology, Changchun, China \\ Correspondence: Lihua Geng, Changchun University of Science and Technology, Changchun 130022, China. \\ E-mail: glh@cust.edu.cn
}

Received: October 8, 2013 Accepted: November 1, 2013 Online Published: November 22, 2013

doi:10.5539/hes.v3n6p53

URL: http://dx.doi.org/10.5539/hes.v3n6p53

\begin{abstract}
As one of the development trends in world education, multicultural education has been confronted with a lot of difficulties in the globalization tide that becomes more and more open. On the basis of making an analysis of the background and connotation of generation of multicultural education, this paper reflects on multicultural education in China. In addition, the author of this paper expounds how a teacher ought to adapt to the trend of multicultural education in China by combination of her own professional background and proposes new requirements.
\end{abstract}

Keywords: globalization, multicultural education, reflection, teacher

\section{The Background and Connotation of Multicultural Education}

\subsection{The Background of Production of Multicultural Education}

Multicultural education originated from the United States and has gradually become one of the most important features in its education system. The theory of multicultural education has also been adopted and applied in other countries and regions in the world. Under the influence of this tide of educational theory, at the end of the $20^{\text {th }}$ Century, a diversity of studies that focus on multicultural education theory in China raised large amount of concerns and gradually became one of the components in the study of multicultural education in the world. Meanwhile, the conflict between diverse culture and education is still escalating with increasing violent globalization trend. Therefore, based on the understanding of formation background and research features of multicultural education, how to put the theory into practice under specific Chinese educational system would be of important theoretical and realistic significance.

The concept of "multicultural education" was developed on the basis of "multiethnic education". At that time, in order to mitigate contradictions and conflicts between multiple nationalities, the proposal of "multiethnic education" was put forward, which laid stress on the education issue of minority ethnic groups. Later on, women and persons with a disability also asked for equal treatment by the society. The connotation and denotation of the concept of "multiethnic education" became more enriched and gradually developed to the idea of multicultural education (Wang \& Yang, 2009). The basic feature of multicultural education was that it was generated based on the diversified culture between different ethnic groups. Western society went through three ideologies, as assimilation, integration and multivariate, to match up the differences between different cultures of ethnic groups during different historical stages. The thought of multiculturalism directly gave rise to generation of multicultural education. The first tide of multicultural education arose in the US in the $60 \mathrm{~s}$ of the $20^{\text {th }}$ Century. At the time, society should face an influx of immigrants moving into the US who comes from different cultural backgrounds. The evolution of the theory of multicultural education has undergone a complex process in the US, from the very beginning of ethnic group contention of equality, to acknowledgement of cultural diversification and diversity, and finally come into the whole specific and systematic development of multicultural education theory (Wan, 2008).

It is important to understand that diversification is the core of multicultural education. With constant processing of modernization, the process of globalization is also accelerated. The process of accelerated globalization will further emphasize the diversification of culture. "It seems that cultural practice will also be unusually complex" (cited from the course reading material "Globalization, Universities and New Knowledge"). Therefore, under the 
background of globalization, it is necessary to construct a multicultural education environment, promote development of multicultural education and pay attention to discrepancy of culture and equality of opportunities. This helps to "cultivate the adaptability capacity and development capacity of all students in the multicultural world, promote diversified development among varied world culture, improve mutual respect of different cultures, and finally facilitate the peace of the whole world". Above all, multicultural education has been a new mission in the current era of globalized times (Chen, 2005). Acceleration of the process of globalization brings light to cultural discrepancy of different nationalities. The western culture, especially related to the American culture, has aroused intense impact to the culture of other countries. In this sense, multicultural education is the key to resolve multicultural conflicts under a background of globalization.

\subsection{The Connotation of Multicultural Education}

A lot of scholars have given definitions to the concept of multicultural education. For instance, Jamese. A. Banks (1988) treated multicultural education as a kind of reflection on ideas for the purpose of enabling all students from different cultures and different ethnic group backgrounds to have access to equal educational opportunities and the same learning treatment from school and teachers (Banks, 1988). There were also some scholars who regarded multicultural education practice as a kind of means to ensure social equity and fairness. Nevertheless, the connotation of multicultural education is still quite broad that need to further solve the problem of explicit demarcation. As an outcome of the western national Risorgimento, multicultural education is generally thought to be a kind of concept, idea and educational movement (Wang, 2003). More like a kind of educational theoretical idea, in the process of actual education, multicultural education actually has not formed an integrated teaching and course system with common consensus that has a practical operability to really help with the actual teaching and learning (Wan, 2008). As a matter of fact, generation and development of multicultural education is the integration of cultural consciousness of different ethnic groups on education as the inevitable outcome of social reality in western countries.

\section{Critical Reflection on Multicultural Education}

\subsection{Criticism on Multicultural Education at Abroad}

Foreign countries have different degrees of doubt with multicultural education whether in theory or in practice. In theory, there have, all along, been a lot of disputes on multicultural education in western countries. However, it is exactly these disputes that encourage scholars from all parts of the world to reflect on the current multicultural education theories and continuously detect a lot of contradictions in the development process of multicultural education. Foreign scholars make several critics on the theory of multicultural education. Firstly, it is thought that multicultural education is a new kind of racialism, which may covers up class contradictions, but fails to eliminate inequality in the society, and finally may not solve the essential issue in the debate. Secondly, it is believed that multicultural education might give rise to reduction of basic capacity of students, even foster their values of nihilism. The third issue focuses on the bias of the concept. It is deemed that the fundamental concept of multicultural education, in itself, is implicit, which would further decrease the ability of rational thinking in the implication and diverse purpose of multicultural education. Fourthly, it is regarded that a judgment standard is lacked when considered the cultural value of multicultural education. All the critics and doubts above related to the theory of multicultural education, as a matter of fact, are the reflection of different standpoints and attitudes of different theoretical schools. In a word, no uniformed theory is formed until now. In terms of practice, what are the practical achievements of multicultural education in the western world? Let's take US and Australia as an example. Although the idea and understanding of multicultural education in American has been widely penetrated, when considering its practical effect, it still remains at the level of disputes on cultural identity and discrepancy of different ethnic groups. This makes the deeper issue come to the surface, and difficult to touch and solve the essence of the contradictions. It is also hard to mitigate the living and working conditions of the weak groups and ethnic groups in the society. In Australia, almost all schools accept the policy of multicultural education. It is true that policies in all states have attempted to enable teachers to integrate into the perspective of multi-culture education. Nonetheless, the actual implementation is merely symbolic, especially in the schools that do not have a lot of immigrant students (Xu \& Qin, 2004). Although most teachers tried to make the best use of multiple and integration theory, when using in the actual teaching assignment, they still felt no idea to solve the practical problems for lack of sense of multi-cultural perspective and field experience.

It is obvious that multicultural education has faced up with a lot of dilemma and unsolved problems both in terms of theory and in terms of practice. What's more, the increasingly accelerated globalization is also making a dent in the root of diversity of culture, as "mutual penetration of similarity and feature is complex and difficult" (cited from the reading material "The Intense Situation of the Globe and Local Areas: A Comparative 
Demonstration of Reconstruction of Higher Education in China in the 50s and in the $90 \mathrm{~s}$ of the $20^{\text {th }}$ Century). With globalization of economy, the values and way of life led by US have continuously attacked culture of other countries in the world. Even within the country itself, the mainstream culture is also continuously dispelling the culture of the weak class (Liu \& Li, 2007). Similarly, this phenomenon was also happened in China. For example, in the current China, the way of living among a new generation of minority ethnic young people has changed to have no great difference compared with the Han Nationality, while they are totally different in old days, that they only wear their national dress, speak their dialect and isolated from the world. However, with the development of globalization, their artistic form and customs and habits have been gradually overwhelmed in the current of the historical development. Although multicultural education is faced up with a lot of difficulties, from the perspective of human kind's pursuit of diversity and its thinking on the value of existence, we have reasons to believe that the proposal of multicultural education won't and shouldn't lose its significance when confront with the current dilemma (Wan, 2007).

\subsection{Reflection on Multicultural Education in China}

Although an explicit proposal of multicultural education has not been put forward in the educational policy of the country, multicultural education is equipped with favorable soil for development, since China is always an abundant country with multiple nationalities and multiple traditional cultures. What's more, the preference for son over daughters was also deep rooted in some agricultural communities following the traditional culture for decades. Thus, especially in education on minority ethnic nationalities and education on girls, the idea of multicultural education has sprouted earlier than other country. Ever since the 1990s, people in the educational realm started to draw attention to deal the educational problem caused by cultural factors, and have conducted large amounts of exploratory studies on multicultural education. However, at present, studies on both theory and practice of multicultural education in China are still at an initial stage due to diverse theoretical viewpoints that filled with lots of disputes. The multicultural education in China has a large discrepancy from the multicultural education in western countries whether in terms of the education mode of national cultural background or in terms of the guiding thought. Therefore, it is still open for further discussion whether we should regard multicultural education as the foundation of national education or not. From the perspective of the background, connotation and critics of multicultural education, multicultural education is consistent with the political, economic and social development of the US society. Thus, it can be said that multicultural education is a local education theory of the United States. It can also be found that, the internal logic of the theoretical system of multicultural education is not as consistent with the social and economic development of the current China as in the US. The specific path of the theory and implementation of multicultural education is supposed to be different in different countries and at different historical stages.

According to the author of this paper, multicultural education in China ought to have Chinese characteristics. We may refer to the ideas of multicultural education in western countries in terms of theory of multicultural education, and make necessary integration and improvements by taking into consideration of our national situation (Wang, Qin, Luan, \& Guan, 2007). Practices of multicultural education in other countries also indicate that the theory of multicultural education needs to be localized. Implementation of multicultural education should have different paths. Development of multicultural education in China should not only search for scientific evidence in terms of theory, but also make constant explorations in terms of practice to form a stable operation mode, which may suited to Chinese national conditions (Qian, 2011).

\section{Requirements of Multicultural Education for Teachers}

In studies on educational theories, teachers' education of multi-culture gradually becomes an important subject. Teachers play a multiple role in multicultural education. Therefore, teachers have to possess the concept and capacity to adapt to development of multicultural education. Then, how a common teacher ought to adapt to development of multicultural education in China in the future?

First of all, teachers ought to have the basic understanding of multicultural education. Teachers are the main subject in teaching of multi-culture. Only when teachers have full comprehension in different cultures and histories of all ethnic groups, possess the idea of multicultural education and use a multicultural viewpoint to explain all kinds of social contradictions and problems, can students really establish the consciousness of multi-culture, understand and show respect for different cultures. It's meaningful to use a critical thinking in a multicultural society to obtain better survival and development. A teacher without the idea of multicultural education is unable to adapt to teach under the background of multicultural education. The basic features of cross-cultural teachers are reflected in the four aspects of knowledge, technology, intension and emotion of teachers. Only when teachers have a comprehensive understanding of multicultural education, can they better 
follow up the changes of globalization. Through exploration for almost half a century, the suggestive mode of multicultural teacher training in the Unites States has been approaching to maturity in the aspects of training content, task, training stage and professional development of teachers (Wang, 2007).

Secondly, teachers are required to take the initiative in embodying cultural diversity in the process of teaching and education. For example, diversity of cultural factors can be reflected in all the actual educational details of designing the teaching plan, selecting the suitable teaching method and or using the proper referential teaching materials. However, it is worth to be noticed that, at the time of emphasizing the cultural diversity, the common social core value should not be ignored (Lin, 1994). Teachers should find the balance of these two. They should treat their students in a vision of multiculturalism and help students to make clear understanding of similarities and differences between diverse cultures. Moreover, teachers are required to let students come to realize relationships between different cultures in spanning from one culture to another. Students are encouraged to identify and understand the culture they belong to, meanwhile show their respect to the culture of others. Teachers may try their best to encourage students to be more tolerant and more comfortable in learning in a multicultural environment.

Finally, teachers are required to have the capacity of critical analysis, and then further cultivate this critical thinking capacity to their students. It can be regarded as a basic purpose of multicultural education that enable students to have opportunity to touch with, comprehend and show respect for different cultures. It is also important for students to show respect for the people from different culture background. If the teachers are lacking in a critical analysis capacity, it would lead the students feel perplexed, and lose the capacity of judgment in the face of the situation of multi-culture. Students may feel confuse when dealing with the tough situation, which may make multi-culture conflicts more obvious. As a consequence, they might accept some inferior culture. And more than that, some might become an empty value neutralist. Thus, teachers are required to go deeply to comprehend and respect cultural differences, the key of which is to have the capacity of critical analysis. Teaching combined with the thought of multi-culture should not be limited to culture and value themselves, but should also pay attention to cultivating students' capacity of critical analysis. In this way, "students can thinking critically, to find where the differences lie, to do things in different ways, to make a moral judgment, and to take actions based on a conscious process" (cited from the course reading material Globalization, "Knowledge Economy" and Education). This is convenient for students to have a correct understanding and get a mastery of their own culture and culture of others. In addition, in the process of teaching of multicultural education, it is a must for teachers to come to realize the importance of basic knowledge and basic capacity. If too much attention was put on all the minor details of the educational process, but ignore the major target of education, namely, mastery of students' basic knowledge and capacity, then the target of multicultural teaching will be distorted (Lin, 1994).

\section{References}

Banks, J. A. (1988). Multicultural Education: Theory and Practice (p. 115). Boston: Ally and Bacon.

Chen, S.-J. (2005). On the Mission of Multicultural Education in the Perspective of Globalization. Comparative Education Review, 2005(12), 37-41.

Lin, Q. (1994). Multicultural Course (pp. 73-74). Taipei: Taipei Normal University Books.

Liu, H., \& Li, Y. (2007). Harmony in Diversity—Perspective of Multi-culture and Multicultural Education under the Background of Globalization. Journal of Guangzhou University (Social Science Edition), 2007(3), 57-65.

Qian, M.-H. (2011). Brief Discussion on the Idea and Practice of Multicultural Education. Journal of Peking University (Philosophy and Social Sciences), 2011(3), 133-136.

Wan, M.-G. (2007). Dilemma and Development of Multi-cultural Education. Journal of Northwest Normal University (Social Sciences), 2007(1), 58-62.

Wan, M.-G. (2008). Multi-cultural Education from "Diversity" to "Acknowledgement". Educational Research, 2008(11), 87-94.

Wan, M.-G. (2008). Multi-cultural Education from "Diversity" to "Acknowledgement". Educational Research, 2008(11), 87-94.

Wang, J. (2003). Century Dispute on Multicultural Education. Guizhou Ethnic Studies, 2003(1).

Wang, J. (2007). Teacher Training under the Background of Multicultural Education in US. Elementary \& Secondary Schooling Abroad, 2007(10), 16-20. 
Wang, J., Qin, J.-C., Luan, X.-F., \& Guan, Y. (2007). To Figure out Multi-culture Education in China. Guizhou Ethnic Studies, 2007(1), 145-150.

Wang, S.-J, \& Yang, Z.-S. (2009). Characteristics, Nature and Problem of Multicultural Education under the Perspective of Postmodernism. Journal of Northeast Normal University (Philosophy and Social Sciences), 2009(6), 192-197.

Xu, J.-C., \& Qin, Z.-G. (2004). Review on Multicultural Education in Australia. Studies in Foreign Education, 2004(3), 51-56.

Zheng, J.-Z. (2009). Multi-cultural Education: Research in the West and Practice in China. Tribune of Education Culture, 2009(1), 15-25.

\section{Copyrights}

Copyright for this article is retained by the author(s), with first publication rights granted to the journal.

This is an open-access article distributed under the terms and conditions of the Creative Commons Attribution license (http://creativecommons.org/licenses/by/3.0/). 